\title{
Isolation and Structure Elucidation of Five New Asterriquinones from Aspergillus, Humicola and Botryotrichum Species
}

\author{
Ursula Mocek*, Lauri Schultz, Tim Buchan, Charles Baek ${ }^{\dagger}$, Larry Fretto ${ }^{\dagger}$, \\ JERry NZEREM $^{\dagger}$, LOUIS SEHL ${ }^{\dagger}$ and UMA Sinha ${ }^{\dagger}$ \\ Natural Products Chemistry Services, Panlabs, Inc., \\ 11804 North Creek Parkway South, Bothell, WA 98011, U.S.A. \\ ${ }^{\dagger}$ COR Therapeutics, Inc., \\ 256 East Grand Avenue, South San Francisco, CA 94080, U.S.A.
}

(Received for publication February 19, 1996)

Five new quinone pigments have been discovered from the fermentation broth of Aspergillus, Humicola and Botryotrichum species isolated from different soil samples. These compounds inhibit serine proteases of the coagulation pathway. Their structures which differ in the identity and position of a 5-carbon side chain on the indole moiety have been elucidated based on NMR and FAB-MS experiments.

The purple antibiotic, cochliodinol, isolated from Chaetomium species was the first asterriquinone structure reported. ${ }^{1,2)}$ Asterriquinone ( $N$-1,1-dimethylallyl indolyl benzoquinone) has been isolated from Aspergillus terreus $^{3)}$ and exhibited antitumor activity. ${ }^{4)}$ A number

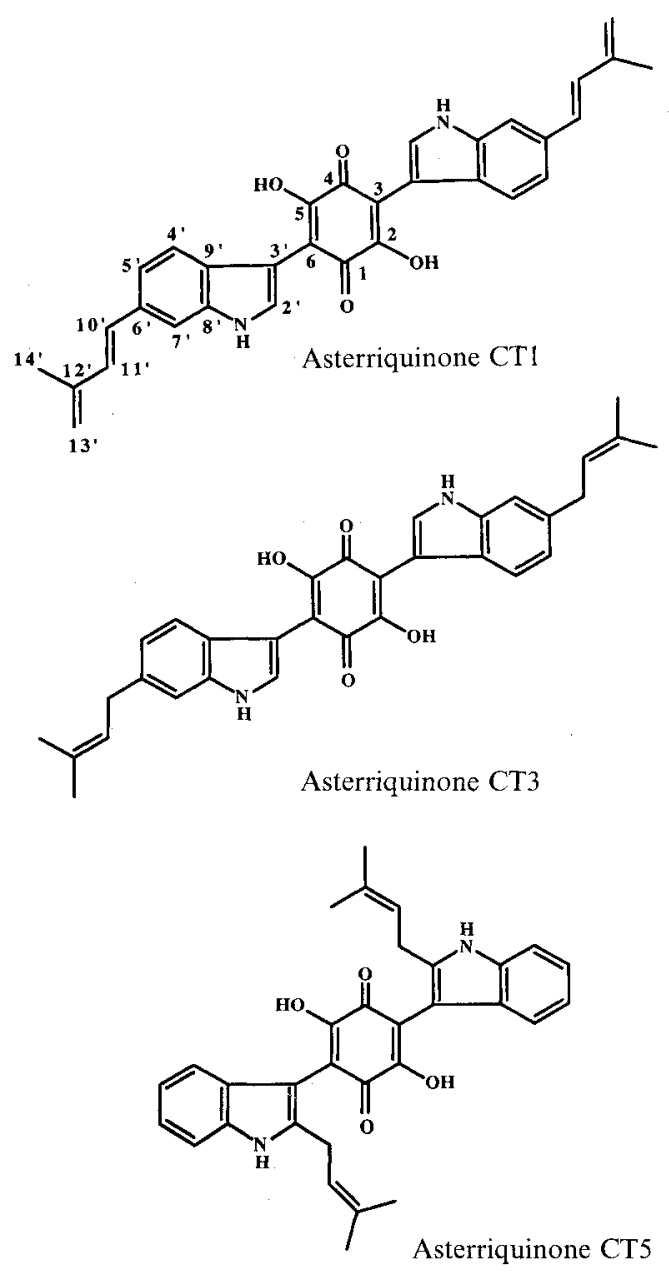

of other indolyl benzoquinones (now commonly called asterriquinones) with either 1,1-dimethylallyl and/or 3,3-dimethylallyl side chain(s) in different positions of the indole moiety have been found in Aspergillus terreus. ${ }^{5}$ In addition, several corresponding quinols and deriva-

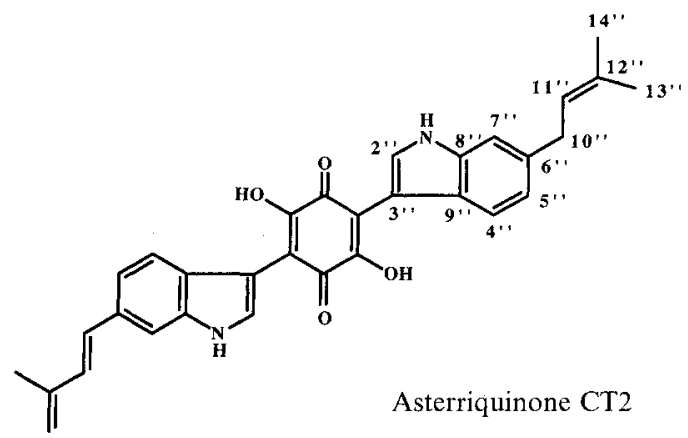

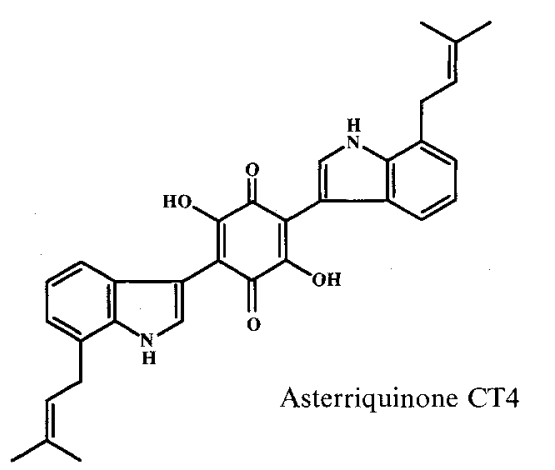


tives have been isolated from the same organism. ${ }^{6)}$ The chemistry of these compounds has also been studied extensively. ${ }^{7,8)}$ Herein, we describe the isolation, structure elucidation, and biological properties of five new metabolites.

\section{Materials and Methods}

\section{General Experimental Procedures}

NMR spectra were recorded at $300 \mathrm{~K}$ on a Bruker $500 \mathrm{MHz}$ DRX spectrometer and on a Bruker $300 \mathrm{MHz}$ AC spectrometer. The samples for NMR characterization were dissolved in DMSO- $d_{6}$ at a concentration of approximately 5 to $10 \mathrm{mg} / \mathrm{ml}$. Mass spectrometry was performed on a PE-Sciex API III triple-quadrupole mass spectrometer interfaced with a Sciex Ion-Spray probe (ES/MS) and on a Fisons VG 70SEQ Tandem Hybrid MS/MS spectrometer (FAB). UV spectra were run on a Perkin-Elmer Lambda 6 spectrometer. IR spectra were recorded on a Perkin-Elmer 1600 FTIR. Melting points were determined using a Electrothermal Engineering Ltd. melting point apparatus and are uncorrected. Pharmacia Sephadex LH-20 was used for column chromatography. Solvents used for chromatographic separations were HPLC grade.

Centrifugal Partition Chromatography (CPC) was performed on a PC, Inc. high speed countercurrent chromatograph containing an Ito multilayer-coil column. A $1: 3: 3: 3 \mathrm{v} / \mathrm{v} / \mathrm{v} / \mathrm{v}$ of $n$-hexane, EtOAc, $\mathrm{MeOH}$ and water was mixed and allowed to settle overnight. The lower layer was pumped into the CPC column as the stationary phase. The upper layer was used as the mobile phase. After 2 hours, the lower and upper layer were switched. The CPC run was completed after 4 hours. The column had a rotation speed of $1,040 \mathrm{rpm}$, and a flow rate of $3 \mathrm{ml} / \mathrm{minute}$ was used. Overall 80 fractions of $9 \mathrm{ml}$ each were collected, whereby the last fraction is the column wash generated by blowing air through the column and dissolving the residue in $\mathrm{MeOH}(9 \mathrm{ml})$. The injection size was between 400 to $500 \mathrm{mg}$ of crude extract dissolved in upper and lower phase ( $5 \mathrm{ml}$ each). A Waters 991 photo diode array detector was used monitoring at $270 \mathrm{~nm}$. All fractions were assayed and active fractions were pooled and evaporated under reduced pressure to dryness.

Protease Inhibition Assay for Factor Xa, Thrombin and Trypsin

Factor $\mathrm{Xa}(1 \mathrm{~nm})$ in $20 \mathrm{~mm}$ Tris $\mathrm{HCl}, 0.15 \mathrm{M} \mathrm{NaCl} \mathrm{pH}$ 7.5 was treated with different concentrations of inhibitor for 5 minutes at room temperature. After preincubation, S-2765 (Pharmacia Hepar) was added to a final concentration of $0.1 \mathrm{~mm}$ in the incubation mixture. The rate of $p$-nitroanilide cleavage was monitored at $405 \mathrm{~nm}$ by a 96 well plate reader. Thrombin and trypsin were assayed by analogous protocols using Chromozym TH (Boehringer Mannheim) and S-2222 (Pharmacia Hepar) as substrates, respectively.

Factor VIIa/Tissue Factor Complex Inhibition Assay The assay consists of preincubation of various amounts of inhibitor, factor VIIa $(0.5 \mathrm{nM})$ and lipidated recombinant tissue factor $(0.5 \mathrm{nM})$ (Dade) for 5 minutes at room temperature. The proteolytic substrate factor $\mathrm{X}$ was added and activated for 20 minutes at $37^{\circ} \mathrm{C}$. Quenched aliquots were assayed for activation of factor $\mathrm{X}$ using S-2765. The standard curve of factor Xa generation by an equivalent amount of untreated factor VIIa after similar incubations was used for calculation of $\mathrm{IC}_{50}$ values.

\section{Prothrombinase Inhibition Assay}

Inhibition of prothrombinase activity was carried out by an adaptation of a previously described procedure. ${ }^{9)}$ The activation was monitored in a 96 well format by following the time course of thrombin generation using Chromozym TH as substrate. The assay consists of preincubation of inhibitor, factor $\mathrm{Xa}(0.5 \mathrm{nM})$, factor $\mathrm{Va}$ ( $2 \mathrm{nM})$ and phosphatidyl serine: phosphatidyl choline $(25: 75,20 \mu \mathrm{M})$. Withdrawn aliquots were assayed for activation of prothrombin. The standard curve of thrombin generation by an equivalent amount of untreated factor $\mathrm{Xa}$ after similar incubations was used for the calculation of $\mathrm{IC}_{50}$ values.

\section{Results and Discussion}

Producing Organisms

The microorganisms were isolated by us from soil samples collected in Nevada, U.S.A. and different areas of Mexico and identified at the International Mycological Institute in the UK. ${ }^{10}$ )

Asterriquinone CT1: The soil sample was found in Chiapas, Mexico and the producing strain was identified as Humicola fuscoatra Traaen, a rather common species in soil.

Asterriquinone CT4: The original producing strain also collected in Chiapas, Mexico was tentatively identified to be the same strain (Humicola fuscoatra Traaen), although the prepared subculture was sterile.

Asterriquinone CT3: The producing microorganism was found in a soil sample in Chichenitza, Mexico and shown to be Humicola grisea Traaen, again fairly common in soil.

Asterriquinone CT2: A Botryotrichum species was isolated from a soil sample collected in Yucatan, Mexico. It is not $B$. piluliferum, but close to $B$. peruvianum Matsush.; possibly an undescribed organism.

Asterriquinone CT5: The common fungal strain Aspergillus terreus was isolated from a soil sample found in Nevada, U.S.A. 


\section{Fermentation}

The inoculum suspension $(1 \mathrm{ml})$ was transferred into each flask containing $25 \mathrm{ml}$ of seed medium consisting of glucose $20 \mathrm{~g}$, pharmamedia $15 \mathrm{~g},\left(\mathrm{NH}_{4}\right)_{2} \mathrm{SO}_{4} 3 \mathrm{~g}$, $\mathrm{ZnSO}_{4} \cdot 7 \mathrm{H}_{2} \mathrm{O} 30 \mathrm{mg}, \mathrm{CaCO}_{3} 4 \mathrm{~g}$, and yeast extract $5 \mathrm{~g}$ in 1 liter of tap water. The flasks were placed on a rotary shaker at $250 \mathrm{rpm}$ for 48 hours at $28^{\circ} \mathrm{C}$ in darkness. Then $1 \mathrm{ml}$ of cell suspension was inoculated into each flask containing $30 \mathrm{ml}$ of the production medium A consisiting of glucose $20 \mathrm{~g}$, sucrose $50 \mathrm{~g}$, pharmamedia $20 \mathrm{~g}, \mathrm{NaNO}_{3}$ $1 \mathrm{~g}, \mathrm{~K}_{2} \mathrm{HPO}_{4} 0.5 \mathrm{~g}, \mathrm{KCl} 0.7 \mathrm{~g}$, L-histidine $1 \mathrm{~g}$, and $\mathrm{MgSO}_{4} \cdot 7 \mathrm{H}_{2} \mathrm{O} 14 \mathrm{mg}$ in 1 liter of tap water, $\mathrm{pH} 7.0$, for asterriquinones CT2, 3, and 4. Production medium $\mathrm{B}$ consisiting of mannitol $60 \mathrm{~g}$, soybean meal $12.5 \mathrm{~g}$, citric acid $2.5 \mathrm{~g}$, and yeast extract $0.5 \mathrm{~g}$ in 1 liter of tap water, $\mathrm{pH} 7.0$, was used for asterriquinones CT1 and 5. The flasks were placed on a rotary shaker using the same conditions as before. After six days, $10 \mathrm{ml}$ of ethyl acetate was added to each flask, and the fermentation was harvested.

\section{Isolation}

The whole fermentation mixtures were each filtered through cheesecloth by suction filtration. The filtrates were extracted twice with $0.25 \mathrm{v} / \mathrm{v}$ of ethyl acetate. The combined extracts were evaporated under reduced pressure to dryness. The mycelia were briefly homogenized and then extracted twice with $0.4 \mathrm{v} / \mathrm{v}$ of ethyl acetate. The ethyl acetate layers from each extract were combined and the solvent removed by rotary evaporation. Asterriquinones CT1 and 2 were not soluble in the $\mathrm{CPC}$ solvent mixture and were removed by filtration. Asterriquinone CT4 was present in the column wash. All three compounds were not further purified. The crude metabolites CT3 and 5 eluted off the CPC column from 21 to 30 and 15 to 27 minutes, respectively. The active fractions were pooled, dried and then partitioned between $n$-hexane and $10 \%$ aqueous methanol. In both cases, the activity resided in the aqueous methanol layers which were dried and then applied to a Sephadex LH-20 column. Both compounds CT3 and CT5 eluted with methanol as purple bands. Asterriquinones CT 1, 2, 3, 4 and 5 yielded $22,217,7.3,141$, and $13 \mathrm{mg} /$ liter, respectively.

\section{Physical and Spectroscopic Data}

Asterriquinone CT1: Black powder; mp $350 \sim 355^{\circ} \mathrm{C}$ (dec); ${ }^{1} \mathrm{H}$ and ${ }^{13} \mathrm{C}$ NMR, Table 1; IR (KBr) cm ${ }^{-1} 3369$, $1609,1333,1274$ and $1245 ; \lambda_{\max } \mathrm{nm}(\log \varepsilon) 470$ (3.79), 305 (4.68); molecular formula: $\mathrm{C}_{32} \mathrm{H}_{26} \mathrm{~N}_{2} \mathrm{O}_{4}$; HRMSFAB, $m / z 503.1970$ calcd for $\mathrm{C}_{32} \mathrm{H}_{27} \mathrm{~N}_{2} \mathrm{O}_{4}$, found
503.1971 .

Asterriquinone CT2: Black powder; $\mathrm{mp} \sim 350^{\circ} \mathrm{C}$ (dec); ${ }^{1} \mathrm{H}$ and ${ }^{13} \mathrm{C}$ NMR, Table 1; IR (KBr) cm ${ }^{-1} 3354,1611$, 1329 and $1282 ; \lambda_{\max } \mathrm{nm}(\log \varepsilon) 470$ (3.64), 303 (4.82); molecular formula: $\mathrm{C}_{32} \mathrm{H}_{28} \mathrm{~N}_{2} \mathrm{O}_{4}$; HRMS-FAB, $m / z$ 505.2127 calcd for $\mathrm{C}_{32} \mathrm{H}_{29} \mathrm{~N}_{2} \mathrm{O}_{4}$, found 505.2122.

Asterriquinone CT3: Dark purple powder; mp $\sim 300^{\circ} \mathrm{C}$ (dec); ${ }^{1} \mathrm{H}$ and ${ }^{13} \mathrm{C}$ NMR, Table 1; IR (KBr) $\mathrm{cm}^{-1} 3350,2927,1613,1332$ and $1280 ; \lambda_{\max } \mathrm{nm}(\log \varepsilon)$ 452 (3.61), 297 (4.45); molecular formula: $\mathrm{C}_{32} \mathrm{H}_{30} \mathrm{~N}_{2} \mathrm{O}_{4}$; HRMS-FAB, $m / z 507.2277$ calcd for $\mathrm{C}_{32} \mathrm{H}_{31} \mathrm{~N}_{2} \mathrm{O}_{4}$, found 507.2283

Asterriquinone CT4: Dark purple powder; mp 295 $300^{\circ} \mathrm{C}$ (dec); ${ }^{1} \mathrm{H}$ and ${ }^{13} \mathrm{C}$ NMR, Table 1 ; IR $(\mathrm{KBr}) \mathrm{cm}^{-1}$ $3359,1617,1337$ and 1276; $\lambda_{\max } \mathrm{nm}(\log \varepsilon) 470$ (3.79), 303 (4.43); molecular formula: $\mathrm{C}_{32} \mathrm{H}_{30} \mathrm{~N}_{2} \mathrm{O}_{4}$; HRMS$\mathrm{FAB}, m / z \quad 507.2286$ calcd for $\mathrm{C}_{32} \mathrm{H}_{31} \mathrm{~N}_{2} \mathrm{O}_{4}$, found 507.2284 .

Asterriquinone CT5: Dark purple powder; $\mathrm{mp}$ $\sim 300^{\circ} \mathrm{C}$ (dec); ${ }^{1} \mathrm{H}$ and ${ }^{13} \mathrm{C}$ NMR, Table 1 ; IR (KBr) $\mathrm{cm}^{-1} 3354,2922,1641,1458,1338$ and 1280; $\lambda_{\max } \mathrm{nm}$ $(\log \varepsilon) 448$ (3.70), 295 (4.49); molecular formula: $\mathrm{C}_{32} \mathrm{H}_{30} \mathrm{~N}_{2} \mathrm{O}_{4} ;$ HRMS-FAB, $m / z 507.2283$ calcd for $\mathrm{C}_{32} \mathrm{H}_{31} \mathrm{~N}_{2} \mathrm{O}_{4}$, found 507.2272.

\section{Structure of Asterriquinone CT3}

The high resolution FAB-MS proposed a molecular formula of $\mathrm{C}_{32} \mathrm{H}_{30} \mathrm{~N}_{2} \mathrm{O}_{4}$. The NMR data indicated a symmetrical dimer. The ${ }^{1} \mathrm{H}$ NMR spectrum showed two methyl groups ( $\delta 1.69)$, a methylene group ( $\delta 3.38)$ and one olefin proton $(\delta 5.32)$ which are all part of the same spin system in the COSY spectrum and indicative of a 3,3-dimethylallyl moiety. The HMBC experiment verified the presence of this side chain displaying the following correlations: $\delta 1.69$ to $\mathrm{C}-12^{\prime}\left(\delta\right.$ 131.81) and $\mathrm{C}-11^{\prime}(\delta$ $125.17)$ as well as from $\delta 3.38$ to $\mathrm{C}-12^{\prime}(\delta 131.81), \mathrm{C}-11^{\prime}$ $(\delta 125.17), \mathrm{C}-7^{\prime}(\delta 111.17), \mathrm{C}-6^{\prime}(\delta 134.95)$ and $\mathrm{C}-5^{\prime}(\delta$ 120.54).

Based on the assignment of known indole structures, ${ }^{11)}$ the quaternary carbons at $\delta 105.34,125.51$ and 136.93 and the methine carbon $(\delta 111.17)$ were assigned to $\mathrm{C}-3^{\prime}$, C- $-8^{\prime}, \mathrm{C}-9^{\prime}$ and $\mathrm{C} 7^{\prime}$, respectively. The indole $\mathrm{NH}(\delta 11.17)$ as well as $\mathrm{H}-2^{\prime}(\delta 7.40), \mathrm{H}-4^{\prime}(\delta 7.30)$ and $\mathrm{H}-5^{\prime}(\delta 6.78)$ were then assigned on the basis of their coupling constants and long-range correlations. The proton at position $7^{\prime}$ $(\delta 7.11$ ) was identified through its HMQC correlation with $\mathrm{C}-7^{\prime}$. Because this proton is a singlet the 3,3dimethylallyl moiety must be attached at the $6^{\prime}$ position ( $\delta$ 134.95). This was further supported by HMBC correlations of the methylene protons in the side chain 
Table 1. ${ }^{1} \mathrm{H}$ and ${ }^{13} \mathrm{C}$ NMR chemical shifts of asterriquinones $\mathrm{CT} 1 \sim 5$.

\begin{tabular}{|c|c|c|c|c|c|c|}
\hline \multirow[b]{2}{*}{$\begin{array}{l}\text { Carbon } \\
\text { No. }^{a}\end{array}$} & \multicolumn{2}{|r|}{ Asterriquinone $\mathrm{CT} 1$} & \multicolumn{2}{|r|}{ Asterriquinone CT2 } & & \\
\hline & $\begin{array}{l}{ }^{13} \mathrm{C} \text { chemical } \\
\text { shifts (ppm) }\end{array}$ & $\begin{array}{l}{ }^{1} \mathrm{H} \text { chemical } \\
\text { shifts }(\mathrm{ppm})^{\mathrm{C}}\end{array}$ & $\begin{array}{l}{ }^{13} \mathrm{C} \text { chemical } \\
\text { shifts (ppm) }\end{array}$ & $\begin{array}{l}{ }^{1} \mathrm{H} \text { chemical } \\
\text { shifts }(\mathrm{ppm})^{\mathrm{c}}\end{array}$ & & \\
\hline C-3 & 110.96 & & 110.96 & & & \\
\hline$C-6$ & 110.96 & & 111.33 & & & \\
\hline $\mathrm{C}-2,5-\mathrm{OH}$ & & $10.77(2 \mathrm{H}, \mathrm{brs})$ & & $10.73(2 \mathrm{H}, \mathrm{br} s)$ & & \\
\hline $\mathrm{NH}-1^{\prime}$ & & $1 \mathrm{l} .45(2 \mathrm{H}, \mathrm{brs})$ & & $11.45(1 \mathrm{H}, \mathrm{brs})$ & & \\
\hline $\mathrm{NH}-1^{\prime \prime}$ & & & & $11.24(1 \mathrm{H}, \mathrm{brs})$ & & \\
\hline $\mathrm{C}-2^{\prime}$ & 128.38 & $7.53(2 \mathrm{H}, \mathrm{d}, J=2.3 \mathrm{~Hz})$ & 128.40 & $7.53(1 \mathrm{H}, \mathrm{d}, J=2.4 \mathrm{~Hz})$ & & \\
\hline C-2" & & & $126: 96$ & $7.44(1 \mathrm{H}, \mathrm{s})$ & & \\
\hline$C-3^{\prime}$ & 104.76 & & 104.74 & & & \\
\hline$C-3^{\prime \prime}$ & & & 104.20 & & & \\
\hline $\mathrm{C}-4^{\prime}$ & 121.75 & $7.40(2 \mathrm{H}, \mathrm{d}, J=8.5 \mathrm{~Hz})$ & 121.75 & $7.40(1 \mathbf{H}, \mathrm{d}, J=8.3 \mathrm{~Hz})$ & & \\
\hline$C-4^{\prime \prime}$ & & & 121.44 & $7.33(1 \mathrm{H}, \mathrm{d}, J=8.13 \mathrm{~Hz})$ & & \\
\hline $\mathrm{C}-5^{\prime}$ & 117.27 & $7.24(2 \mathrm{H}, \mathrm{d}, J=8.5 \mathrm{~Hz})$ & 117.29 & $7.24(1 \mathrm{H}, \mathrm{d}, J=8.42 \mathrm{~Hz})$ & & \\
\hline$C-5^{\prime \prime}$ & & & 119.78 & $6.82(1 \mathrm{H}, \mathrm{d}, J=8.3 \mathrm{~Hz})$ & & \\
\hline$C-6^{\prime}$ & $130.1 \mathrm{I}$ & & 130.13 & & & \\
\hline$C-6^{\prime \prime}$ & & & 134.18 & & & \\
\hline$C-7^{\prime}$ & 110.08 & $7.49(2 \mathrm{H}, \mathrm{s})$ & 110.08 & $7.49(1 \mathrm{H}, \mathrm{s})$ & & \\
\hline C- $7^{\prime \prime}$ & & & 110.37 & $7.18(1 \mathrm{H}, \mathrm{s})$ & & \\
\hline$C-8^{\prime}$ & 126.32 & & 126.32 & & & \\
\hline C-8" & & & 124.59 & & & \\
\hline C- $9^{\prime}$ & 136.07 & & 136.08 & & & \\
\hline $\mathrm{C}-9^{\prime \prime}$ & & & 136.08 & & & \\
\hline$C-10^{\prime}$ & 130.18 & $6.69(2 \mathrm{H}, \mathrm{d}, J=16.1 \mathrm{~Hz})$ & 130.18 & $6.70(1 \mathrm{H}, \mathrm{d}, J=16.1 \mathrm{~Hz})$ & & \\
\hline$C-10^{\prime \prime}$ & & & 33.90 & $\sim 3.40(2 \mathrm{H}, \mathrm{m})$ & & \\
\hline$C-11^{\prime}$ & 128.94 & $6.94(2 \mathrm{H}, \mathrm{d}, J=16.1 \mathrm{~Hz})$ & 128.96 & $6.96(1 \mathrm{H}, \mathrm{d}, J=16.1 \mathrm{~Hz})$ & & \\
\hline$C-11^{\prime \prime}$ & & & 124.29 & $5.35(1 \mathrm{H}, \mathrm{t} J=7.2 \mathrm{~Hz})$ & & \\
\hline$C-12^{\prime}$ & 141.96 & & 141.97 & & & \\
\hline C-12" & & & 130.98 & & & \\
\hline \multirow[t]{2}{*}{$C-13^{\prime}$} & 116.27 & $5.14(2 \mathrm{H}, \mathrm{s})$ & 116.28 & $5.14(1 \mathrm{H}, \mathrm{s})$ & & \\
\hline & & $5.03(2 \mathrm{H}, \mathrm{s})$ & & $5.03(1 \mathrm{H}, \mathrm{s})$ & & \\
\hline $\mathrm{C}-13^{\prime \prime}$ & & & 25.57 & $1.75(3 \mathrm{H}, \mathrm{s})$ & & \\
\hline C-14' & 18.58 & $1.95(6 \mathrm{H}, \mathrm{s})$ & 18.58 & $1.95(3 \mathrm{H}, \mathrm{s})$ & & \\
\hline \multirow{2}{*}{$\mathrm{C}-14^{\prime \prime}$} & & & 17.71 & $\sim 1.70(3 \mathrm{H}, \mathrm{s})$ & & \\
\hline & \multicolumn{2}{|r|}{ Asterriquinone CT3 } & \multicolumn{2}{|r|}{ Asterriquinone CT4 } & \multicolumn{2}{|r|}{ Asterriquinone CT5 } \\
\hline $\begin{array}{c}\text { Carbon } \\
\text { No. }\end{array}$ & $\begin{array}{l}{ }^{13} \mathrm{C} \text { chemical } \\
\text { shifts (ppm) }\end{array}$ & $\begin{array}{l}{ }^{1} \mathrm{H} \text { chemical } \\
\text { shifts (ppm) }\end{array}$ & $\begin{array}{l}{ }^{13} \mathrm{C} \text { chemical } \\
\text { shifts (ppm) }\end{array}$ & $\begin{array}{l}{ }^{1} \mathrm{H} \text { chemical } \\
\text { shifts }(\mathrm{ppm})\end{array}$ & $\begin{array}{l}{ }^{13} \mathrm{C} \text { chemical } \\
\text { shifts (ppm) }\end{array}$ & $\begin{array}{l}{ }^{1} \mathrm{H} \text { chemical } \\
\text { shifts (ppm) }\end{array}$ \\
\hline$C-3,6$ & 111.70 & & 111.16 & & 110.54 & \\
\hline $\mathrm{C}-2,5-\mathrm{OH}$ & & $10.75(2 \mathrm{H}, \mathrm{brs})$ & & $10.66(2 \mathrm{H}, \mathrm{brs})$ & & $10.70(2 \mathrm{H}, \mathrm{brs})$ \\
\hline $\mathrm{NH}-\mathrm{l}^{\prime}$ & & $11.17(2 \mathrm{H}, \mathrm{brs})$ & & $11.29(2 \mathrm{H}, \mathrm{brs})$ & & $10.94(2 \mathrm{H}, \mathrm{s})$ \\
\hline $\mathrm{C}-2^{\prime}$ & 127.64 & $7.40(2 \mathrm{H}, \mathrm{d}, J=1.8 \mathrm{~Hz})$ & 127.07 & $7.45(2 \mathrm{H}, \mathrm{d}, J=2.1 \mathrm{~Hz})$ & 137.56 & \\
\hline C. $-3^{\prime}$ & 105.34 & & 104.83 & & 104.20 & \\
\hline$C-4^{\prime}$ & 122.33 & $7.30(2 \mathrm{H}, \mathrm{d}, J=7.9 \mathrm{~Hz})$ & 119.18 & $7.22(2 \mathrm{H}, \mathrm{d}, J=7.9 \mathrm{~Hz})$ & 119.34 & $7.14(2 \mathrm{H}, \mathrm{d}, J=7.5 \mathrm{~Hz})$ \\
\hline$C-5^{\prime}$ & 120.54 & $6.78(2 \mathrm{H}, \mathrm{dd}, J=8.0,0.9 \mathrm{~Hz})$ & 118.86 & $6.88(2 \mathrm{H}, \mathrm{dd}, J=7.9,6.9 \mathrm{~Hz})$ & 118.17 & $6.87(2 \mathrm{H}, \mathrm{t}, J=7.4 \mathrm{~Hz})$ \\
\hline $\mathrm{C}-6^{\prime}$ & 134.95 & & 120.02 & $6.85(2 \mathrm{H}, \mathrm{d}, J=6.9 \mathrm{~Hz})$ & 119.87 & $6.97(2 \mathrm{H}, \mathrm{dd}, J=7.9,7.4 \mathrm{~Hz})$ \\
\hline$C-7^{\prime}$ & 111.17 & $7.11(2 \mathrm{H}, \mathrm{s})$ & 124.29 & & 110.54 & $7.28(2 \mathrm{H}, \mathrm{d}, J=7.9 \mathrm{~Hz})$ \\
\hline$C-8^{\prime}$ & 125.51 & & 126.47 & & 128.04 & \\
\hline C- $-9^{\prime}$ & 136.93 & & 134.44 & & 135.36 & \\
\hline $\mathrm{C}-10^{\prime}$ & 34.78 & $3.38(4 \mathrm{H}, \mathrm{d}, J=7.3 \mathrm{~Hz})$ & 29.07 & $3.54(4 \mathrm{H}, \mathrm{d}, J=7.4 \mathrm{~Hz})$ & 26.33 & $3.31(4 \mathrm{H}, \mathrm{d}, J=6.4 \mathrm{~Hz})$ \\
\hline $\mathrm{C}-11^{\prime}$ & 125.17 & $5.32(2 \mathrm{H}, \mathrm{L}, J=7.3 \mathrm{~Hz})$ & 122.26 & $5.43(2 \mathrm{H}, \mathrm{t}, J=7.2 \mathrm{~Hz})$ & 121.16 & $5.26(2 \mathrm{H}, \mathrm{t}, J=6.3 \mathrm{~Hz})$ \\
\hline$C-12^{\prime}$ & 131.81 & & 132.03 & & 131.86 & \\
\hline $\mathrm{C}-13^{\prime}$ & 26.43 & $1.69(6 \mathrm{H}, \mathrm{s})$ & 25.55 & $1.70(6 \mathrm{H}, \mathrm{s})$ & 25.40 & $1.67(6 \mathrm{H}, \mathrm{s})$ \\
\hline C-14' & 18.53 & $1.69(6 \mathrm{H}, \mathrm{s})$ & 17.74 & $1.71(6 \mathrm{H}, s)$ & 17.50 & $1.63(6 \mathrm{H}, \mathrm{s})$ \\
\hline
\end{tabular}

a $\mathrm{C}-1,2,4$, and 5 were not observed in ${ }^{13} \mathrm{C}$ NMR spectra.

b Chemical shifts are shown with reference to DMSO- $d_{6}$ as $39.5 \mathrm{ppm}$.

c Chemical shifts are shown with reference to DMSO- $d_{6}$ as $2.49 \mathrm{ppm}$.

at position $11^{\prime}(\delta 3.38)$ with carbons $\mathrm{C}^{\prime} 5^{\prime}(\delta 120.54), \mathrm{C}-6^{\prime}$ $\left(\delta\right.$ 134.95) and $\mathrm{C}^{-} 7^{\prime}(\delta$ 111.17) of the indole ring. Based on the assignment of related asterriquinones, $\mathrm{C}-3$ and C-6 resonate at $\delta$ 111.70. Carbon atoms 1, 2, 4, and 5 were not observed in the ${ }^{13} \mathrm{C}$ NMR spectrum due to the resonance of the benzoquinone ring.

\section{Structure of Asterriquinone CT1}

A molecular formula of $\mathrm{C}_{32} \mathrm{H}_{26} \mathrm{~N}_{2} \mathrm{O}_{4}$ was determined for asterriquinone $\mathrm{CT} 1$ by high resolution FAB-MS indicating a loss of four protons compared to asterriquinone CT3. From the ${ }^{1} \mathrm{H}$ NMR spectrum it was immediately clear that the 3,3-dimethylallyl moiety is no longer present. Again, the NMR spectra suggested that 
the structure is a symmetrical dimer.

The ${ }^{1} \mathrm{H}$ NMR spectrum showed a methyl group ( $\delta$ 1.95), a terminal methylene ( $\delta 5.03$ and 5.14) and a trans olefin ( $\delta 6.69$ and $6.94, J=16.1 \mathrm{~Hz}$ ) indicating a 3-methyl-1,3-butadienyl moiety. The following longrange correlations in the $\mathrm{HMBC}$ experiment supported this notion: $\delta 1.95$ to $\mathrm{C}-13^{\prime}(\delta 116.27), \mathrm{C}-12^{\prime}(\delta 141.96)$ and $\mathrm{C}-11^{\prime}(\delta 128.94) ; \delta 5.03$ and 5.14 to $\mathrm{C}-14^{\prime}(\delta$ 18.58) and $\mathrm{C}-11^{\prime}(\delta 128.94) ; \delta 6.69$ to $\mathrm{C}-12^{\prime}(\delta 141.96)$ and $\mathrm{C}-5^{\prime}$ $(\delta 117.27) ; \delta 6.94$ to $\mathrm{C}-10^{\prime}(\delta 130.18)$.

The same considerations used for the assignment of the indole moiety of asterriquinone CT3 were applied to asterriquinone CT1. The quaternary carbons at $\delta 104.76$, 126.32, and 136.07 were assigned to $\mathrm{C}-3^{\prime}, \mathrm{C}-8^{\prime}$ and $\mathrm{C}-9^{\prime}$, and the indole methine at $\delta 110.08$ was assigned to $\mathrm{C}-7^{\prime}$. The indole $\mathrm{NH}(\delta 11.45)$ as well as $\mathrm{H}^{-2}{ }^{\prime}(\delta 7.53), \mathrm{H}-4^{\prime}$ $(\delta 7.40)$ and $\mathrm{H}-5^{\prime}(\delta 7.24)$ could then be identified based on their coupling constants and long-range correlations. The HMQC spectrum showed that the singlet at $\delta 7.49$ is attached to $\mathrm{C}-7^{\prime}$. Therefore the side chain must again be attached at the C- $6^{\prime}$ position which is also confirmed by a long-range correlation from $\mathrm{H}-11^{\prime}$ to $\mathrm{C}-6^{\prime}(\delta 130.18)$.

\section{Structure of Asterriquinone CT4}

The structure of asterriquinone CT4 is almost identical to that of asterriquinone CT3 with the following exceptions: the methine carbon at $\mathrm{C}-7^{\prime}$ which was readily identified by its characteristic chemical shift of $\sim 110 \mathrm{ppm}$ is not present, but instead a new quaternary carbon at $\delta 124.29$ appears. The protons at $\mathbf{H}-4^{\prime}(\delta 7.22), \mathbf{H}-5^{\prime}(\delta$ 6.88 ) and $H-6^{\prime}(\delta$ 6.85) form a contiguous spin system with ortho couplings between $\mathrm{H}-4^{\prime}$ and $\mathrm{H}-5^{\prime}$ as well as H-5' and H-6'. The methylene protons in the $10^{\prime}$ position $(\delta 3.54)$ show long-range correlations to C- $6^{\prime}(\delta$ 120.02), C-7' $(\delta$ 124.29) and C-9' $(\delta$ 134.44). Based on these data, the 3,3-dimethylallyl side chain is connected at the $7^{\prime}$ position.

\section{Structure of Asterriquinone CT5}

The structure of asterriquinone CT5 again varies just slightly from that of asterriquinone CT3. The protons at $\mathrm{C}-4^{\prime}(\delta 7.14), \mathrm{C}-5^{\prime}(\delta 6.87), \mathrm{C}-6^{\prime}(\delta 6.97)$ and C-7' $(\delta 7.28)$ form a spin system as indicated by coupling constants and COSY experiments. The carbon at position $2^{\prime}$ is now a quaternary carbon and shifted downfield to $\delta 137.56$. Further, there is a long-range correlation from $\mathrm{H}-10^{\prime}(\delta$ $3.31)$ to $\mathrm{C}-2^{\prime}(\delta$ 137.56). Therefore, the 3,3-dimethylallyl side chain is attached at the $2^{\prime}$ position.

\section{Structure of Asterriquinone CT2}

Unlike the other four asterriquinones, this metabolite is not a symmetrical dimer which was immediately clear from the ${ }^{1} \mathrm{H}$ and ${ }^{13} \mathrm{C}$ NMR spectra. Upon careful examination of the data, it was apparent that the left hand portion of the molecule is identical to that of asterriquinone $\mathrm{CT} 1$ and the right hand portion of the molecule is identical to that asterriquinone CT3.

\section{Biological Data}

The effect of the asterriquinones on proteolytic activity of several blood coagulation cascade enzymes was measured as described under Materials and Methods. Concentrations required for half maximal inhibition are shown in Table 2. Factors VIIa and Xa exhibit $10^{4}$ and $10^{5}$ fold higher catalytic activity when they are incorporated into calcium dependent phospholipid complexes containing cofactors and enzyme. ${ }^{12)}$ Thus the capacity of the metabolites to inhibit coagulation complexes and not structurally related serine proteases such as thrombin and trypsin make them useful as specific inhibitors. Coagulation complexes have been implicated in conditions such as deep vein thrombosis, and coagulation inhibitors may be suitable as therapeutic treatment.

\section{Summary}

We have isolated and characterized five new asterriquinones. All five have been isolated for the first time as natural products, although asterriquinone CT5 was previously known ${ }^{7}$ as a rearrangement product provided by acid catalyzed demethylation of asterriquinone ( $N$-1,1-dimethyl indolyl benzoquinone). Asterriquinones CT1 and 2 are novel structures containing an unique 3-methyl-1,3-butadienyl side chain moiety. In addition to their characteristic purple color, we have

Table 2. $\mathrm{IC}_{50}$ values of asterriquinones $\mathrm{CTl} \sim 5$ for various proteinases in $\mu \mathrm{g} / \mathrm{ml}$.

\begin{tabular}{cccrrr}
\hline Inhibitor & VIIa/TF & Xa/Va & Xa & Thrombin \\
\hline Asterriquinone CT1 & 6 & 8 & 12 & $>200$ \\
Asterriquinone CT2 & 10 & 9 & 27 & 33 \\
Asterriquinone CT3 & 11 & 13 & 18 & $>200$ \\
Asterriquinone CT4 & 15 & 132 & 135 & $>200$ & $>40$ \\
Asterriquinone CT5 & 3 & 12 & $>400$ & $>200$ & $>200$ \\
\hline
\end{tabular}


Fig. 1. FAB mass spectrum of asterriquinone CTl and its expansion of the molecular ion region.

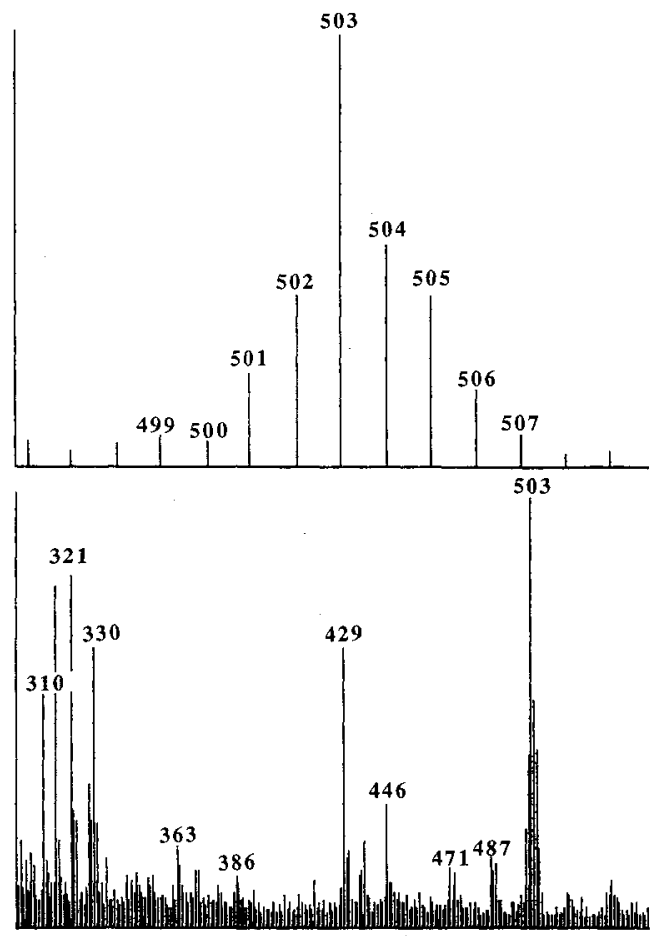

found these compounds to possess distinctive FAB-MS spectra (Fig. 1). These spectra displayed a complex envelope of several lines around the molecular ion with a prominent peak indicating the molecular ion. This feature is due to the resonance of the structures and the number of oxidations and reductions taking place in the molecules.

\section{Acknowledgments}

The authors would like to thank Dr. Dean Glawe, Anne Terry, and Allen CaSEY (Panlabs Biotic Resources) for all their help with the fermentation, Dr. Ross Lawrence (University of Washington, Department of Medicinal Chemistry) for measurement of FAB mass spectra and Prof. Dr. HeINZ Floss (University of Washington, Department of Chemistry) for helpful discussions.

\section{References}

1) Brewer, D.; W. A. JERRAM \& A. TAYLOR: The production of cochliodinol and a related metabolite by Chaetomium species. Can. J. Microbiol. 14: 861 866, 1968

2) MeIler, D. \& A. TAYlor: The effect of cochliodinol, a metabolite of Chaetomium cochliodes, on the respiration of microspores of Fusarium oxysporum. Can. J. Microbiol. 17: $83 \sim 86,1971$

3) Yamamoto, Y.; K. Nishimura \& N. KiriYama: Studies on the Metabolic Products of Aspergillus terreus. I. Metabolites of the strain IFO 6123. Chem. Pharm. Bull. 24: $1853 \sim 1859,1976$

4) Yamamoto, Y.; N. Kiriyama, S. Shimizu \& S. Koshimura: Antitumor activity of asterriquinone, a metabolic product from Aspergillus terreus. Gann 67: $623 \sim 624,1976$

5) Arai, K.; K. Masuda, N. Kiriyama, K. Nitta, Y. Yamamoto \& S. Shimizu: Metabolic products of Aspergillus terreus. IV. Metabolite of the strain IFO 8835. (2). The isolation and structure of indolyl benzoquinone pigments. Chem. Pharm. Bull. 29: $961 \sim 969,1981$

6) Arai, K.; S. Shimizu \& Y. Yamamoto: Metabolic products of Aspergillus terreus. VI. Metabolites of the strain IFO 8835. (3). The isolation and chemical structures of colorless metabolites. Chem. Pharm. Bull. 29: $1005 \sim 1012,1981$

7) Arai, K.; S. Shimizu, Y. Taguchi \& Y. Yamamoto: Metabolic products of Aspergillus terreus. V. Demethylation of asterriquinones. Chem. Pharm. Bull. 29: 991 999, 1981

8) Jerram, W. A.; A. G. Mcinnes, W. S. G. Maass, D. G. Smith, A. TAYlor \& J. A. Walter: The chemistry of cochliodinol, a metabolite of Chaetomium spp. Can. J. Chem. 53: $727 \sim 737,1975$

9) Sinha, U.; T. E. Hancock, J. J. Nzerem, P. H. Lin, J. E. TOMLinson \& D. L. Wolf; Effect of gamma carboxylation on prothrombinase inhibitory activity of catalytically inactive factor Xa. Thrombosis Research 75: $427 \sim 436,1994$

10) The strains were identified at the International Mycological Institute in Bakeham Lane, Egham, Surrey TW20 9TY, UK by Drs. P. M. KirK and Z. LAwrEnCE.

11) Cole, R. J. \& R. H. Cox: Handbook of Toxic Fungal Metabolites. pp. 463 483, Academic Press, New York, 1981

12) Mann, K. G.; M. E. Nesheim, W. R. Church, P. Haley \& S. Krishnaswamy: Review: Surface-dependent reactions of the vitamin $\mathrm{K}$-dependent enzyme complexes. Blood 76: $1 \sim 16,1990$ 